\title{
The Buzet Thrust Fault in Istria and overturned carbonate megabeds in the Eocene flysch of the Dragonja Valley (Slovenia)
}

\section{Buzetski narivni prelom v Istri in inverzne karbonatne megaplasti v eocenskem flišu v dolini Dragonje}

\author{
Ladislav PLACER ${ }^{1, *}$, Adrijan KOŠIR ${ }^{2}$, Tomislav POPIT ${ }^{2}$, Andrej S̆MUC $^{2}$ \& Grega JUVAN ${ }^{3}$ \\ ${ }^{1}$ Geološki zavod Slovenije, Dimičeva 14, 1000 Ljubljana, Slovenija \\ ${ }^{2}$ Paleontološki inštitut Ivana Rakovea ZRC SAZU, Novi trg 2, 1000 Ljubljana, Slovenija \\ ${ }^{3}$ Oddelek za geologijo NTF, Univerza v Ljubljani, 1000 Ljubljana, Slovenija \\ E-mail: ladislav.placerZ̈geo-zs.si
}

Key words: Tectonies, Buzet Thrust Fault, flysch, carbonate megabeds, Kras Thrust Edge, NW External Dinarides, Adriatic Foreland, Istria, Slovenia, Croatia

Ključne besede: Tektonika, Buzetski narivni prelom, fliš, karbonatne megaplasti, Kraški narivni rob, SZ Zunanji Dinaridi, Jadransko predgorje, Istra, Slovenija, Hrvaška

\begin{abstract}
Detailed geological mapping undertaken in the framework of monitoring of the motorway construction works in SW Slovenia has revealed the existence of a large-scale thrust fault between Buzet and Koper (termed the Buzet Thrust Fault) and extensive thrust-related fold structure which is clearly expressed by overturned carbonate megabeds in the thrust footwall in the eastern part of the Dragonja River basin. The Buzet Thrust Fault represents the southeastern margin of the structurally complex Kras Thrust Edge.

\section{Kratka vsebina}

Pri detajlnem geološkem kartiranju v okviru spremljave zemeljskih del na avtocestnih odsekih v JZ Sloveniji je bil odkrit obsežen narivni prelom, ki poteka med Buzetom in Koprom. V talninski grudi narivnega preloma, ki smo ga poimenovali po Buzetu, se pojavlja pas plasti v inverzni legi. Obnarivna inverzija je najizraziteje vidna v izdankih karbonatnih megaplasti v vzhodnem delu porečja Dragonje. Buzetski narivni prelom predstavlja skrajno jugozahodno mejo strukturno kompleksnega Kraškega narivnega roba.
\end{abstract}

Systematical geological monitoring of the motorway construction works in NW Slovenia carried out during the last few years has provided new insights into the structural and sedimentary evolution of the westernmost External Dinarides and the Adriatic Foreland (Placer, 2002; Placer \& Vrabec, 2004). In order to compile a reference regional profile, geological mapping performed by the Geological Survey of Slovenia and the Institute of Paleontology ZRC SAZU has comprised a narrow belt along the motorway route between Kozina and Srmin and, parallelly, a wider area extending from the Kras edge (Kraški rob) and Čičarija to the eastern part of Istria (Fig. 1). In this short note we report the discovery of a large-scale thrust fault between Štrped near Buzet and Koper (termed the Buzet Thrust Fault), and anextensive thrust-related fold structure which is expressed by overturned carbonate megabeds in the thrust footwall in the east- 
ern part of the Dragonja River basin (Figs. 1, 2).

The study area is composed predominantly of Eocene flysch deposits. While the motorway route between Klanec and Srmin (near Koper) is mostly situated in a structurally complex region, the area between the Bay of Koper and the Dragonja Valley is characterized by a relatively undisturbed flysch succession composed of thin to medi-

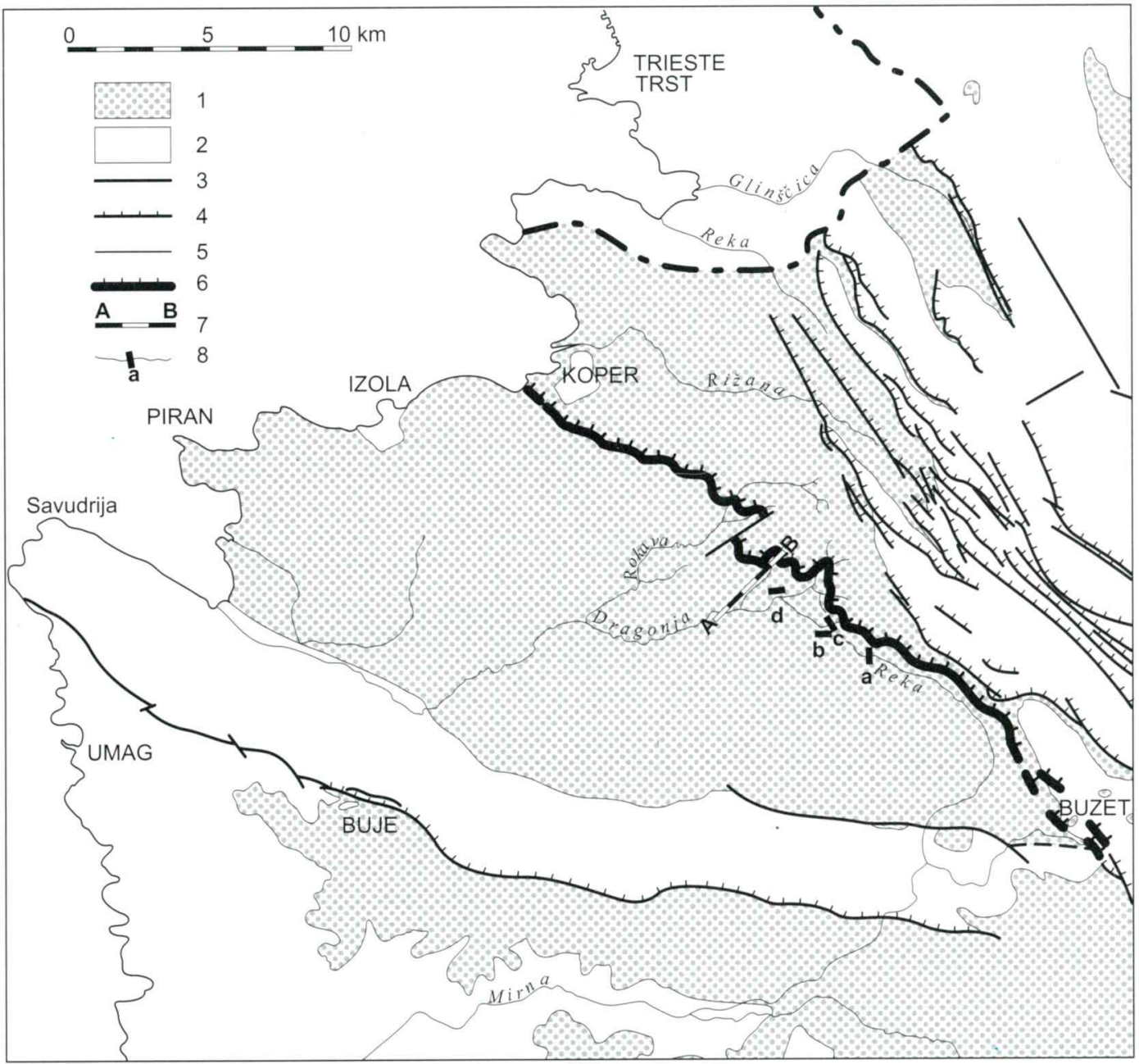

Fig. 1. Trace of the Buzet Thrust Fault shown on the simplified Basic Geological Map 1:100.000, Trst Sheet (Pleničar et al., 1969).

1. Eocene flysch and Quaternary sediments; 2. Cretaceous, Paleocene and Eocene platform carbonates: 3. Normal and strike-slip faults; 4. Reverse fault; 5 . Lithological boundary between the flysch and the underlying carbonates; 6. Trace of the Buzet Thrust Fault; 7. Position of the profile in Fig. 2; 8. Waterfalls on overturned carbonate megabeds: a -Veli Vir, b - Mali Vir, c - Waterfall below the village Trebeše, $\mathbf{d}$ - Waterfall below the village Trsek

S1. 1. Skica poteka Buzetskega narivnega preloma na listu Trst, Osnovna geološka karta 1: 100.000 (Pleničar et al., 1969)

1. Eocenski fliš in in kvartarni sedimenti; 2. Kredni, paleocenski in eocenski karbonati;

3. Normalni prelom, zmični prelom; 4. Reverzni prelom; 5. Litološka meja med eocenskim flišem in podlago; 6. Slednica Buzetskega narivnega preloma; 7. Lega prereza na sl. 2;

8. Slapovi v obrnjenih plasteh: a - Veli Vir, b - Mali Vir, c - slap na Stranici pod Trebešami, d slap pod Trskom. 


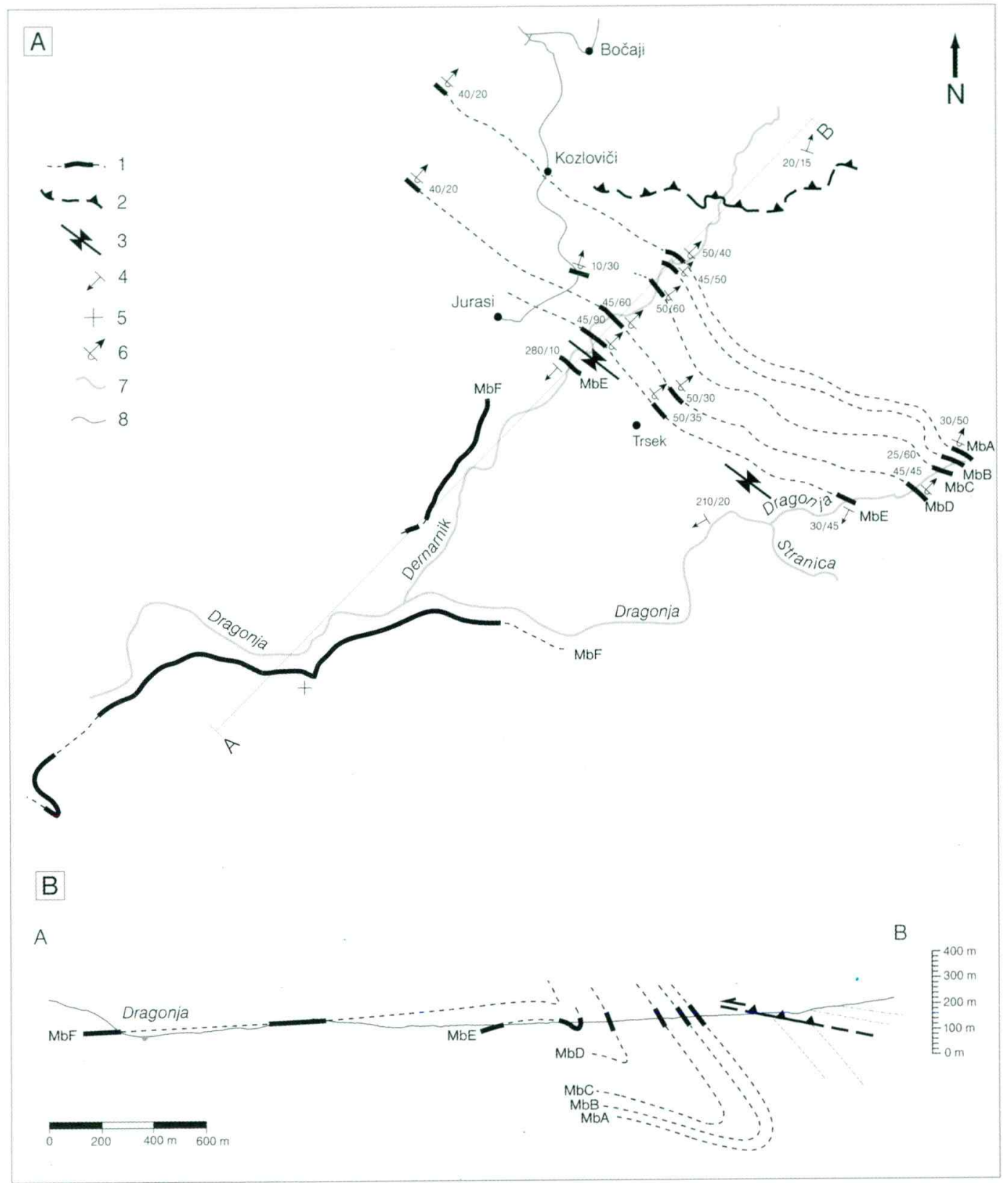

Fig. 2 A. - Sketch of the area mapped in detail showing overturned carbonate megabeds MbA $\mathrm{MbE} ; \mathrm{B}$ - Profile through the thrust zone.

1. Carbonate megabeds; 2. Buzet Thrust Fault; 3. Fold axis; 4. Overturned bedding; 5. Normal bedding; 6 . River, creek; 7 . Road.

Sl. 2 A. - Skica natančneje kartiranega ozemlja z obrnjenimi karbonatnimi megaplastmi MbA $\mathrm{MbE}, \mathrm{B}$ - Prerez narivne cone.

1. Karbonatne megaplasti; 2. Buzetski narivni prelom; 3. Os gube; 4. Obrnjene plasti;

5. Pravilne plasti; 6. Reka, potok; 7. Cesta. 


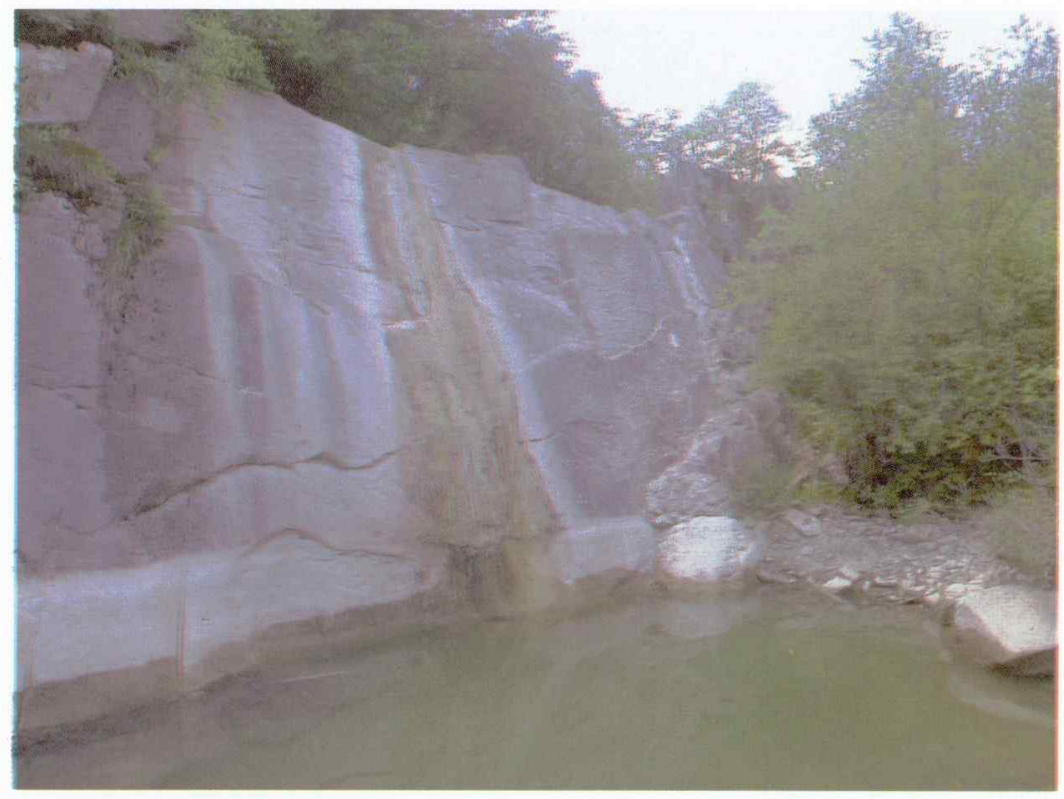

Fig. 3. The waterfall of Veli Vir. Along the rivers of Dragonja and Reka and their tributaries carbonate megabeds gave rise to formation of cascades and high, overhanging cliffs and associated waterfalls. Position of larger waterfalls is indicated in Fig. 1.

Sl. 3. Veli Vir, pogled na slap. Vzdolž

Dragonje in Reke ter njunih pritokov so ob obrnjenih karbonatnih megaplasteh nastali previsni klifi, na katerih so številni slapovi. Lega večjih slapov je označena na sl. 1.

um bedded siliciclastic and carbonate-siliciclastic turbidite sandstones, marls, and meter-thick beds (megabeds) of calciturbidites. Our current stratigraphical research has been primarily aimed at establishing a framework for the correlation between separate parts of the flysch basin, based on mapping of major carbonate megabeds in the Dragonja River basin. Calciturbidite me- gabeds within the flysch in the hinterland of Koper are an order of magnitude thicker than "average" turbidite beds and form widespread Ny stratigraphic markers that can be traced in an area of more than $100 \mathrm{~km}^{2}$. Due to their relatively high resistance to weathering, the megabeds are topographically well-expressed in the field, and hence of substantial importance in geological mapping.

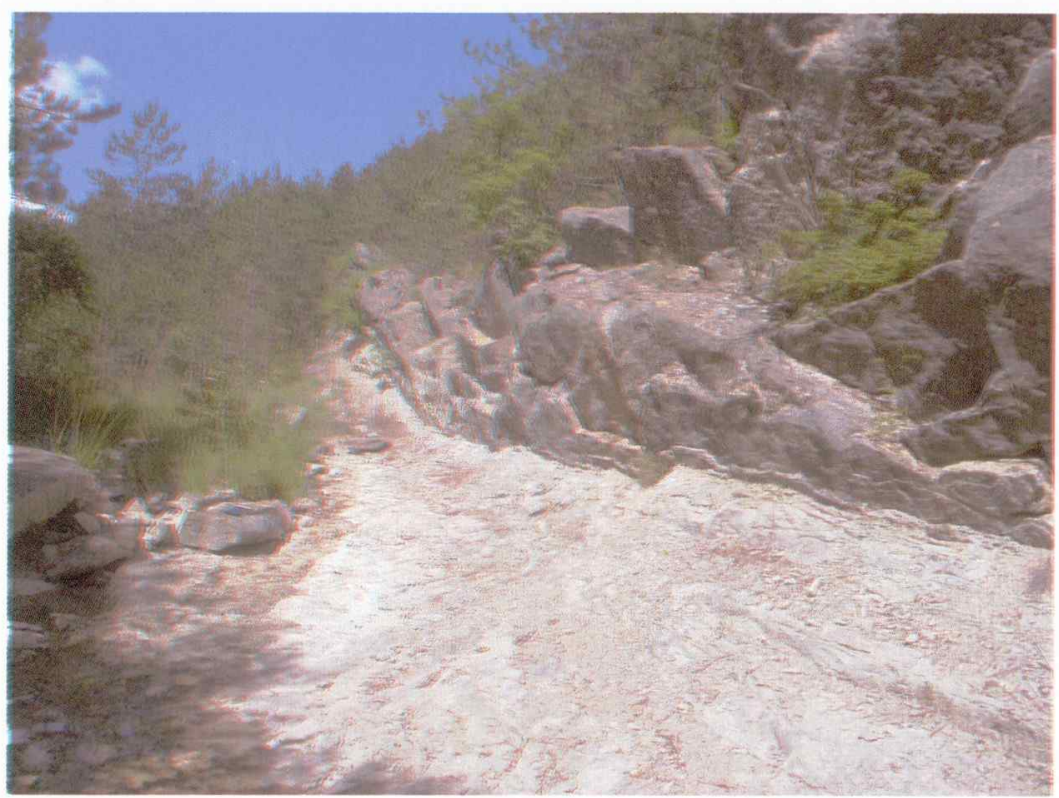

Fig. 4. The waterfall of Veli Vir on the overturned carbonate megabed.

Sl. 4. Veli Vir, pogled na obrnjeno karbonatno megaplast. 


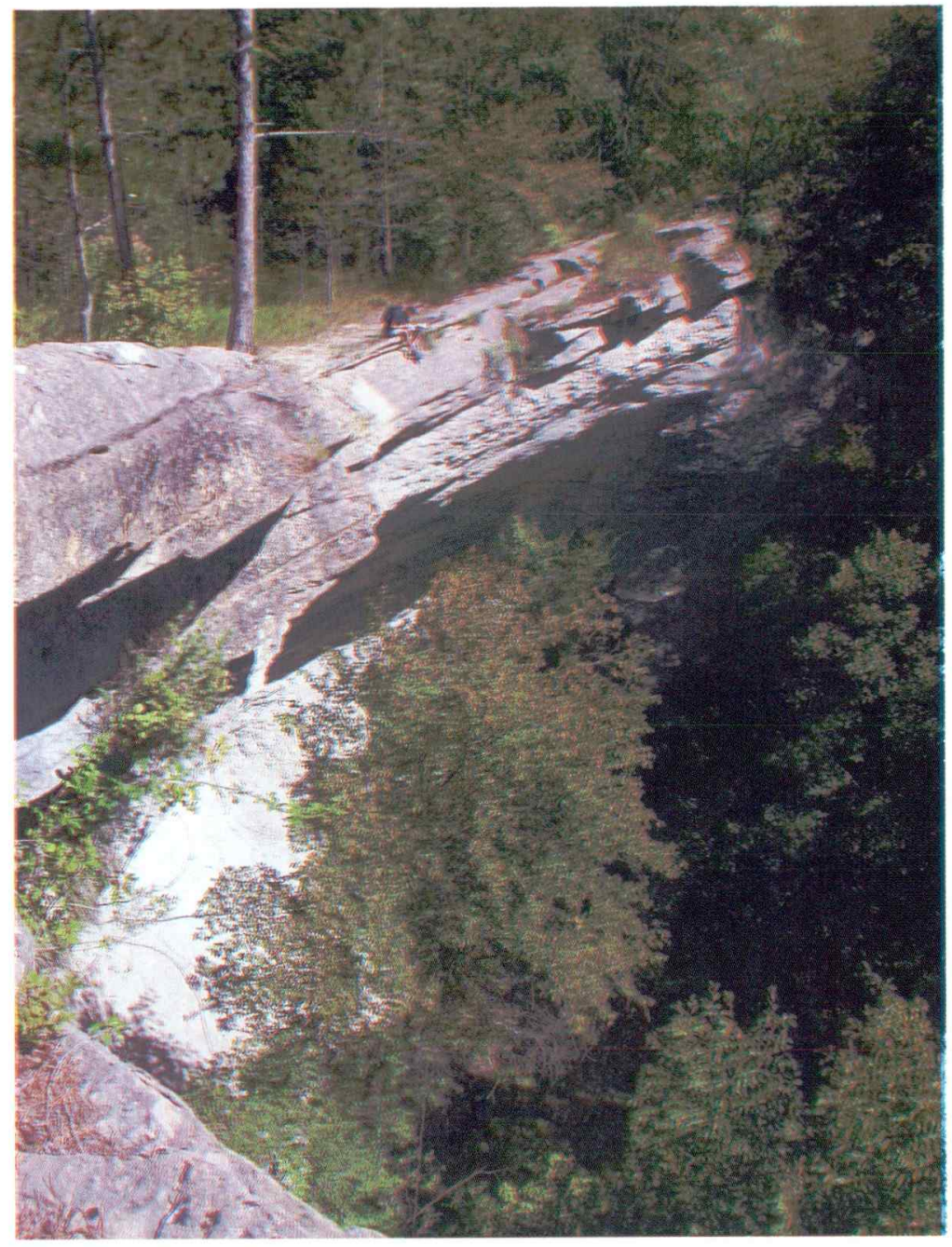

. Fig. 5. The waterfall on the Stranica Creek under Trebeše on the overturned carbonate megabed.

S1. 5. Slap na Stranici pod Trebešami, pogled na slap in obrnjeno karbonatno megaplast.
The significance of megabeds for the reconstruction of the NW Istrian flysch basin was noted by Peckmann (1995) and Pavšič \& Peckmann (1996) who divided the flysch succession in the area of Piran into four units, bounded by meter-scale calciturbidites. Along the Dragonja River and its tributaries we have recognized 4 to 6 calciturbidite and bipartite debrite-calciturbidite beds, up to 7 meters thick, which mostly exhibit graded profiles with internal structures of complete or partial Bouma sequences capped by several meters thick marlstone layer. A characteristic feature in most of the calciturbidites is a distinctive imbrication of nummulite tests in the basal $\left(\mathrm{T}_{\mathrm{a}}\right)$ interval. Preliminary paleotransport measurments based on num- mulite orientation indicate sediment transport from the southwest. Consistently, a downcurrent decrease in bed thickness of calciturbidites can generally be followed in the SW-NE direction.

Flysch deposits in the western part of the Dragonja Valley are horizontally to subhorizontally bedded and are well-exposed in steep cliffs and river channels. In the eastern (upper) part of the Dragonja Valley the bedding turns to subvertical and overturned over short distance, forming an asymmetrical non-plunging syncline fold in the thrust footwall. A simplified map and a profile through the broader thrust zone are shown in Fig. 2. The dip of the thrust plane ranges from 5 to $40 \mathrm{~A} \mathrm{NE}$, depending on local post- 
thrusting deformation. Beds in the thrust footwall are folded and overturned in the thrust direction and generally dipping 40 to $50 \mathrm{~A}$ towards NE. Locally, the overturned beds are nearly horizontal or even gently dip towards SW. The fold structure is best seen in outcrops along the Dernarnik Creek, in road-cuts along the roads near the village of Trsek, and in valleys between the spring of the Dragonja River and its confluence with the Stranica Creek, SE of the Trsek Village (Fig. 2). The bedding in the thrust hanging wall is normal, with a mean strike and dip of 20/15A NE. Carbonate megabeds have not been observed in the hanging wall in the area shown in Fig. 2 but they occur to the northeast in the area of Buzet.

The flysch succession in the overturned fold limb is about $400 \mathrm{~m}$ thick and comprises 6 carbonate megabeds, marked MbA-MbF, according to their stratigraphic position (Fig. 2). The continuation of megabeds between the undeformed western part of the Dragonja Valley and the overturned fold limb has not been established directly; however, as inferred from the altitude of the outcrops of subhorizontal megabeds, the topmost megabed in the eastern part $(\mathrm{MbF})$ presumably corresponds to the innermost megabed in the fold core (Fig. 2B).

Previous understanding of the tectonics of the boundary zone between the External Dinarides and the Adriatic Foreland (Istria) has largely been derived from the Basic Geological Map 1:100.000 (Trst Sheet; Pleničar et al., 1969), which described the Kras Thrust Edge (or Čičarija Zone; Placer \& Vrabec, 2004) as an imbricate structure formed along more or less steep reverse faults (Fig. 1). However, structural data obtained in the recent project of geological mapping of the motorway section Klanec-Srmin
(Pla c e r, 2002) and the newly discovered Buzet Thrust Fault documented in this paper indicate that the Kras Thrust Edge formed through several phases of deformation, including extensive underthrusting of Istria towards NE. The Buzet Thrust Fault, which represents the outermost SW margin of the Kras Thrust Edge, presumably continues from the studied area to the southeast. The broader structural implications of the Buzet Thrust Fault will be addressed in our further work.

\section{Acknowledgment}

The project of geological monitoring of construction works on the motorway section Klanec - Srmin has been funded by the Motorway Company in the Republic of Slovenia (DARS).

\section{References}

Pavšič, J. \& Peckmann, J. 1996: Stratigraphy and sedimentology of the Piran flysch area (Slovenia). - Annales, 9, 123-138, Koper.

Peckmann, J. 1995: Das Flysch-Becken von Piran in Istrien - mit geologischer Kartierung 1:25000. - Diplomarbeit, Inst. Geol. Paläont. Georg-August Univ. Göttingen., 70 pp., Göttingen.

Placer, L. 2002: Predhodna objava strukturnega profiliranja Kraškega roba in Istre (AC Kozina - Srmin, Sečovlje (Preliminary results of structural profiling of the Kras edge and Istria (Kozina - Srmin Motorway, Sečovlje). - Geologija, 45, 227-280. Ljubljana.

Placer, L. \& Vrabec, M. 2004: Neogene structural evolution of the northwestern External Dinarides and Istria Peninsula (Adriatic foreland). - $32^{\text {nd }}$ International Geological Congress, Florence, Scientific Sessions, Abstracts (part 1), 248, Florence.

Pleničar, M., Polšak, A. \& Šikić, D. 1969: Osnovna geološka karta SFRJ 1:100.000, list Trst. - Zvezni geološki zavod, Beograd. 